\title{
Social Entrepreneurship in the World During the Pandemic: State and Development
}

\author{
Kamshat B. Kanapiyanova ${ }^{1 *}$, Rashid M. Ruzanov ${ }^{2}$, \\ Manshuk S. Dosmanbetova ${ }^{3}$, Maral K. Kozhakhmetova ${ }^{4}$, Gulmira N. Appakova ${ }^{4}$ \\ ${ }^{I}$ al-Farabi Kazakh National university, 71 al-Farabi Ave., 050040, Almaty, Kazakhstan \\ ${ }^{2}$ Institute of Economics CS MES RK, 28 Shevchenko Str., A25K1B0, 050000, Almaty, Kazakhstan \\ ${ }^{3}$ University of international business, 8 a Abay ave., 050010, Almaty, Kazakhstan \\ ${ }^{4}$ Narxoz University, 55 Zhandosova str., 050035, Almaty, Kazakhstan,
}

\begin{abstract}
The current economic crisis caused by the Covid-19 pandemic is unprecedented, as it has affected many sectors of the economy. At the same time, first, the SME sector suffered from an economic crisis. The main burden of this crisis falls on the social sphere since it must not only adapt to new challenges but also develop following the requirements of the time. Therefore, the key tasks of today are a revision of the public health system, education, targeted social policy aimed at increasing incomes and improving the quality of life of the population, consolidation of efforts of the state, business, and NGOs to counter new challenges, digitalization of the economy, development of information technologies and their impact on the Kazakh labor market, rural development and modernization of social infrastructure. The world needs the power of social entrepreneurship-hyperactivity, new social changes, which excludes the traditional practice of solving social problems. The whole world is at the crossroads of many crises, so it is necessary to invest in convergent solutions that social entrepreneurs can implement. In these conditions, stimulating the development of social entrepreneurship becomes a fundamental tool for initiating social changes. The article analyzes the state of social entrepreneurship in the context of a pandemic, provides successful examples of solving social problems faced in the world, shows the urgent need for social entrepreneurship in healthcare and other areas as an alternative mechanism for solving social problems, and conducted research on the development of social entrepreneurship in Kazakhstan
\end{abstract}

Keywords: social entrepreneurship, pandemic, government support, quarantine, coronavirus control.

For citation: Kanapiyanova, K.B., Ruzanov, R.M., Dosmanbetova, M.D., Kozhakhmetova, M.K., \& Appakova, G.N. (2021). Social Entrepreneurship in the World During the Pandemic: State and Development. Economics: the Strategy and Practice, 16(4), 102-115, https://doi.org/10.51176/1997-9967-2021-4 -102-115

*Corresponding author: Kamshat B. Kanapiyanova - PhD candidate, al-Farabi Kazakh National university, 71 alFarabi Ave., 050040, Almaty, Kazakhstan, 87714510229, e-mail: kanapiyanova.kamshat@gmail.com

Conflict of interests: the authors declare that there is no conflict of interest

Financial support: This research has been/was/is funded by the Science Committee of the Ministry of Education and Science of the Republic of Kazakhstan (Grant No. APAP09561767)

The article received: 25.06 .2021

The article approved for publication: 21.07 .2021

Date of publication: 30.12 .2021 


\title{
Әлемдегі әлеуметтік кәсіпкерлік пандемия кезінде: жағдайы мен дамуы
}

\author{
Қанапиянова К.Б. ${ }^{*}$, Рузанов Р.М. ${ }^{2}$, Досманбетова М.С. ${ }^{3}$, Кожахметова М.К. ${ }^{4}$, \\ Аппакова Г.Н. ${ }^{4}$ \\ ${ }^{l}$ әл-Фараби атындавы Қазақ Ұлттық университеті, әл-Фараби даңъвыльы, 71, 050040, \\ Алматы, Қазақ̧стан \\ ${ }^{2}$ ҚР БҒМ ҒК Экономика институты, Шевченко 28, А25K1B0, Алматы қ., Қазақстан \\ ${ }^{3}$ Хальқаралық бизнес университеті, Абай даңз. 8а, 050010, Алматық., Қазақста, \\ ${ }^{4}$ Нархоз университеті, Жандосов көшесі 55, 050035, Алматы қ., Қазақсстан
}

\section{Түйін}

Covid-19 пандемиясынан туындаған қазіргі экономикалық дағдарыс - бұрын-соңды болмаған ерекше дағдарыс, өйткені ол экономиканың көптеген салаларына әсерін тигізді. Бұл ретте, ең алдымен экономикалық дағдарыстан ШОБ секторы зардап шекті. Covid-19 - бұл климаттың өзгеруі, гендерлік теңсіздік, нәсілдік әділетсіздік және қазіргі қоғамның негізін бұзатын басқа да жүйелік мәселелер сияқты тұтас төтенше жағдай. Бұл дағдарыстың негізгі жүктемесі әлеуметтік салаға тиесілі, себебі ол жаңа сын-қатерлерге бейімделіп қана қоймай, сонымен қатар уақыт талаптарына сәйкес дамуы керек. Сондықтан да, бүгінгі күннің түйінді міндеттері: қоғамдық денсаулық, білім беру жүйесін қайта қарастыру, халықтың табысын өсіруге және өмір сүру сапасын арттыруға бағытталған атаулы әлеуметтік саясат, жаңа сын-тегеуріндерге қарсы іс-қимыл жасау үшін мемлекеттің, бизнестің және КЕҰ-ның күш-жігерін топтастыру, экономиканы цифрландыру, ақпараттық технологияларды дамыту және олардың қазақстандық еңбек нарығына әсері, ауылдық аумақтарды дамыту және әлеуметтік инфрақұрылымды жаңғырту болып табылады. Пандемия үлкен сынаққа айналды, дегенмен де әр дағдарыстың жарқын жағы да бар. Жаңа оқшаулану және қашықтан жұмыс істеу жағдайында әлеуметтік кәсіпкерлер бизнестегі миссияның болуы ерекше шешімдерді табуға және тіпті ең қиын экономикалық жағдайларда да берілмеуге көмектесетінін тағы бір рет дәлелдеді. Әлемге әлеуметтік кәсіпкерліктің күші қажет - гиперпрактивтілік, жаңа әлеуметтік өзгерістер, бұл әлеуметтік мәселелерді шешудің дәстүрлі тәжірибесін жоққа шығарады. Бүкіл әлем көптеген дағдарыстардың тоғысында тұр, сондықтан әлеуметтік кәсіпкерлер жүзеге асыра алатын конвергентті шешімдерге қаражат салу қажет. Осы жағдайларда әлеуметтік кәсіпкерлікті дамытуды ынталандыру әлеуметтік өзгерістерді тудыру үшін негіз қалаушы құралға айналады. Мақалада пандемия кезіндегі әлеуметтік кәсіпкерліктің жай-күйіне талдау жасалды, әлемде тап болған әлеуметтік мәселелерді шешудің сәтті мысалдары келтірілді, әлеуметтік мәселелерді шешудің балама тетігі ретінде денсаулық сақтау және басқа салалардағы әлеуметтік кәсіпкерліктің өткір қажеттілігі көрсетілді, сондай-ақ Қазақстанда әлеуметтік кәсіпкерлікті дамыту бойынша зерттеулер жүргізілді.

Түйін сөздер: әлеуметтік кәсіпкерлік, пандемия, мемлекеттік қолдау, карантин, коронавируспен күрес.

Дәйексөз алу үшін: Қанапиянова К.Б., Рузанов Р.М., Досманбетова М.С., Кожахметова М.К., Аппакова Г.Н. (2021). Әлемдегі әлеуметтік кәсіпкерлік пандемия кезінде: жағдайы мен дамуы. Экономика: стратегия және практика, 16(4), 102-115, https://doi.org/10.51176/1997-9967-2021-4 -102-115

*Хат-хабаршы авторы: Қанапиянова Камшат Болатқызы - PhD-докторант, әл-Фараби атындағы Қазақ Ұлттық университеті, әл-Фараби даңғылы, 71, 050040, Алматы қ., Қазақстан, 87714510229, е-mail: kanapiyanova.kamshat@gmail.com

Мүдделер қақтығысы: авторлар мүдделер қақтығысының жоқтығын мәлімдейді.

Қаржыландыру: Бұл зерттеуді Қазақстан Республикасы Білім және ғылым министрлігінің Ғылым комитеті қаржыландырады (Грант № АРАР09561767)100

Мақала редакцияға түсті: 25.06 .2021

Жариялау туралы шешім кабылданды: 21.07 .2021

Жарияланды: 30.12 .2021 


\title{
Социальное предпринимательство в мире во время пандемии: состояние и развитие
}

\author{
Канапиянова К.Б. ${ }^{1}$, Рузанов Р.М. ${ }^{2}$, Досманбетова М.С. ${ }^{3}$, Кожахметова М.К. ${ }^{4}$, \\ Аппакова Г.Н. ${ }^{4}$ \\ ${ }^{1}$ Казахский национальный университет им. аль-Фараби, 050040, пр. аль-Фараби, 71, Алматы, \\ Казахстан \\ ${ }^{2}$ Институт экономики КН МОН РК, ул. Шевченко 28, А25К1B0 г. Алматы, Казахстан \\ ${ }^{3}$ Университет международного бизнеса, пр. Абая 8а, 050010, Алматы, Казахстан \\ ${ }^{4}$ Университет Нархоз, ул. Жандосова 55, 050035, Алматы, Казахстан
}

\begin{abstract}
Аннотация
Нынешний экономический кризис, вызванный пандемией Covid-19, является беспрецедентным кризисом, поскольку он затронул многие отрасли экономики. При этом, прежде всего, от экономического кризиса пострадал сектор МСБ. Covid-19-это целая чрезвычайная ситуация, такая как изменение климата, гендерное неравенство, расовая несправедливость и другие системные проблемы, которые разрушают основы современного общества. Основная нагрузка этого кризиса приходится на социальную сферу, поскольку она должна не только адаптироваться к новым вызовам, но и развиваться в соответствии с требованиями времени. Поэтому ключевыми задачами сегодняшнего дня являются: пересмотр системы общественного здоровья, образования, адресная социальная политика, направленная на рост доходов и повышение качества жизни населения, консолидация усилий государства, бизнеса и НКО для противодействия новым вызовам, цифровизация экономики, развитие информационных технологий и их влияние на казахстанский рынок труда, развитие сельских территорий и модернизация социальной инфраструктуры. Пандемия стала большим испытанием, хотя у каждого кризиса есть яркая сторона. В условиях новой изоляции и удаленной работы социальные предприниматели в очередной раз доказали, что наличие миссии в бизнесе помогает находить необычные решения и не сдаваться даже в самых сложных экономических ситуациях. Миру нужна сила социального предпринимательства-гиперактивность, новые социальные изменения, что исключает традиционную практику решения социальных проблем. Весь мир находится на стыке многих кризисов, поэтому необходимо инвестировать в конвергентные решения, которые могут реализовать социальные предприниматели. В этих условиях стимулирование развития социального предпринимательства становится основополагающим инструментом для инициирования социальных изменений. В статье проведен анализ состояния социального предпринимательства в условиях пандемии, приведены успешные примеры решения социальных проблем, с которыми столкнулись в мире, показана острая необходимость социального предпринимательства в здравоохранении и других сферах как альтернативного механизма решения социальных проблем, а также проведены исследования по развитию социального предпринимательства в Казахстане.
\end{abstract}

Ключевые слова: социальное предпринимательство, пандемия, государственная поддержка, карантин, борьба с коронавирусом.

Для цитирования: Канапиянова К.Б., Рузанов Р.М., Досманбетова М.С., Кожахметова М.К., Аппакова Г.Н. (2021). Социальное предпринимательство в мире во время пандемии: состояние и развитие. Экономика: стратегия и практика, 16(4), 102-115, https://doi.org/10.51176/1997-9967-2021-4-102-115

* Корреспондирующий автор: Қанапиянова К.Б. - PhD-докторант, Казахский национальный университет им. аль-Фараби, 050040, пр. аль-Фараби, 71, Алматы, Казахстан, 87714510229, e-mail: kanapiyanova.kamshat@ gmail.com

Конфликт интересов: авторы заявляют об отсутствии конфликта интересов.

Финансирование. Это исследование финансируется Комитетом по науке Министерства образования и науки Республики Казахстан (Грант № АРАР09561767)

Статья поступила в редакцию: 25.06 .2021

Принято решение о публикации: 21.07 .2021

Опубликовано: 30.12 .2021 


\section{Kipicne}

Сегіз ай бұрын дүниежүзілік денсаулық сақтау ұйымы Covid-19 пандемиясын жариялап, бүкіл әлемде әр адамның өмірі өзгерді. Содан бері үкіметтер денсаулық сақтау дағдарысымен ғана емес, сонымен бірге экономикалық салдармен де күресті. Дегенмен де, үміт сәулелері байқалды - көбінесе жаңашыл ойшылдар мен қайраткерлер шұғыл қажеттіліктерді қанағаттандыруға ғана емес, сонымен бірге бүкіл жүйелерді өзгертуге тырысады. Басқаша айтқанда: әлеуметтік кәсіпкерлер.

2009 жылғы H1N1 тұмауы сияқты пандемия Денсаулық сақтау мәселелеріне жаңа көзқарастардың негізін қалап қана қоймай, экономикалық және әлеуметтік мәселелерді шешуге бағытталған жаңа кәсіпкерлік қызметті қолдай отырып, жаһандық қаржылық дағдарысқа қосылды.

Кәсіпкерлер, стартаптар және шағын бизнес пандемиядан қатты зардап шекті және Covid-19 экономикалық көтерілістеріне ең осал топтар болып саналды. Алайда, бұл тізімге Apple сияқты ipi компаниялар және Fortune 1000 тізіміндегі көптеген басқа компаниялар қосылды, олар соңғы айларда жеткізілім тізбегіндегі қиындықтарға тап болды.

Ал Австралиялық JobKeeper схемасы сияқты коронавирустық бизнесті қолдау кейбір әлеуметтік бизнеске пайда азайған кезде де жұмысын жалғастыруға мүмкіндік берді. Технологиялық алпауыт Facebook сонымен қатар 30-дан астам түрлі елдерде 100 миллион доллар көлемінде гранттар беру арқылы көмек көрсетті [1].

\section{Әдебиетке шолу}

Әлеуметтік кәсіпкерлік - бұл өзін-өзі қамтамасыз ету және тұрақтылық жағдайында қоғамның әлеуметтік мәселелерін шешуге немесе жеңілдетуге бағытталған инновациялық қызмет. Ол қызметтің әлеуметтік бағыты мен кәсіпкерлік тәсілді біріктіреді, яғни кәсіпкерлік пен қайырымдылықтың тоғысында болады. Қарапайым тілмен айтқанда, әлеуметтік кәсіпкерлік - бұл жанға қатысты қандай да бір әлеуметтік мәселенің іскери шешімі.

Егер қарапайым кәсіпкерлер пайдаға (сату көлеміне) немесе акциялардың құнына назар аудара отырып, өз қызметінің сәттілігін бағалайтын болса, әлеуметтік кәсіпкерлер де оң «әлеуметтік қайтарымды» ескереді. Әлеуметтік кәсіпкерлік, әдетте, әлеуметтік, мәдени немесе экологиялық мәселелерді шешуге бағытталған және осы тұрғыда ол ерікті (коммерциялық емес) секторға жақындайды. Бұл жағдайда пайда ескерілуі мүмкін, бірақ негізгі мақсат емес, ұйымның әлеуметтік немесе мәдени мақсаттарына жету үшін одан әрі алға жылжу құралы ретінде [2].

Schwab қоры әлеуметтік кәсіпкерлерді «аз қамтылған, маргиналданған немесе осал топтарға ерекше назар аудара отырып, әлеуметтік немесе экологиялық мәселелерді инновациялық түрде шешетін коммерциялық емес, гибридті немесе коммерциялық ұйымдардың негізін қалаушылар» деп анықтайды” [3].

Азаматтық қоғам үшін әлеуметтік кәсіпкерлік жекелеген адамдардың «өзгерістер енгізетін адамдар» ретіндегі құқықтары мен мүмкіндіктерін кеңейту мақсатында жүйелі әлеуметтік өзгерістерде ауқымға қол жеткізу мақсаттарын келісетін жаңа қызмет ағыны бола бастады [4][5]. Үкімет үшін, әсіресе Ұлыбританияда, коммерциялық әлеуметтік кәсіпорын моделі мемлекетті толыққанды жекешелендіруді ұсынбай, әлеуметтік қамсыздандыру бағдарламаларының маркетингіне тартымды көзқарасты ұсынады [6]. Жеке сектор үшін әлеуметтік кәсіпкерлік пирамиданың төменгі жағындағы қозғалыстар сияқты қол жетімді емес нарықтық мүмкіндіктерге қол жеткізу моделін ұсынады; әлеуметтік қамсыздандырудың мемлекеттік бюджеттері және «этикалық» тұтынушылардың өсіп келе жатқан саны [7].

\section{Зерттеу әдіснамасы}

Әдіснамалық және теориялық тұрғыдан зерттеу нарықтық экономика және тұтастай экономикалық трансформация, кәсіпкерлікті дамыту және әлеуметтік кәсіпкерлік институты мәселелері бойынша отандық және шетелдік экономист ғалымдардың классикалық және заманауи ғылыми еңбектеріне негізделген. Зерттеудің әдіснамалық негізі әлеуметтік кәсіпорындардың қоғамдық мотивациясына және олардың экономикалық қорғалмаған азаматтардың әл-ауқатын арттыруда экономикалық маңызды нәтижелерге қол жеткізуіне негізделген мақсатты және әлеуметтік бағдарланған кәсіпкерлік қызметті ұйымдастыру бойынша нарық субъектілері арасындағы экономикалық қатынастардың жиынтығы ретінде әлеуметтік кәсіпкерлікке көзқарас болды.

Зерттеу барысында әлеуметтік кәсіпкерлік нарығын талдаудың кешенді тәсілі қолданылып, жалпы ғылыми және нақты зерттеу, аналитикалық, экономикалық-статистикалық, тарихи-логикалық, салыстыру және жүйелік анализ, сондай-ақ жалпылау, сауалнама жүргізу сияқты әдістері қолданылды. 
Зерттеудің эмпирикалық және ақпараттық базасын Дүниежүзілік Банктің материалдары, Impact Hub Moscow әлеуметтік инновацияларды қолдау орталығының Спбму Жоғары менеджмент мектебінің және Массачусетс университетінің ғалымдарымен бірлескен зерттеу нәтижелері, Қазақстан Республикасы Ақпарат және Қоғамдық Даму Министрлігінің тапсырысы бойынша кешенді әлеуметтік зерттеу шеңберінде Эмин Әскеровтың ақпараттық - талдамалық есебі, кәсіпкерлік қызметті және коммерциялық емес ұйымдардың қызметін регламенттейтін нормативтік-құқықтық құжаттар, экономикалық саясатқа шолулар, ғылыми-зерттеу мекемелерінің, ақпараттық агенттіктер мен қызметтердің ақпараттық және талдамалық материалдары, сондай-ақ бұқаралық ақпарат құралдарының (БАҚ) және интернет желісінің ресурстары құрады.

\section{Нәтижені талқылау}

Дүниежүзілік банктің бағалауы бойынша, COVID-19 салдарынан 100 миллионнан астам адам кедейлікке душар болады, бұл 2017 жылғы кедейлікпен күресте қол жеткізілген барлық жетістіктерді жоққа шығарады. Халықаралық еңбек ұйымының бағалауы бойынша, пандемиядан туындаған экономикалық дағдарыстың нәтижесінде бейресми экономиканың 1,6 миллиардқа жуық қызметкері - еңбек нарығындағы ең осал адамдар - ақша табу қабілетіне үлкен зиян келтірді.

Міне, дәл осы адамдар мен қауымдастықтар әлеуметтік кәсіпкерлерге мұқтаж. БҰҰ Бас хатшысы Антониу Гутерриш атап өткендей, «осы дағдарыс кезінде және одан кейінгі істелініп жатқан барлық нәрсе пандемияға, климаттың өзгеруіне және басқа да жаһандық проблемаларға қарсы неғұрлым тұрақты, тең, инклюзивті және тұрақты экономика мен қоғам құруға бағытталуы керек. Біз барлық әрекет етуші тұлғаларды - әлеуметтік кәсіпкерлерді COVID-19 дағдарысына алғашқы жауапкер және жасыл, инклюзивті қоғам мен экономикалық жүйенің алғашқы бастаушысы ретінде қолдауға шақырамыз».

Бұл дағдарыста әлеуметтік жаңашылдар мен кәсіпкерлер мұқтаж адамдарға қол жетімді медициналық көмек көрсету, жұмыс орындарын қорғау және жедел көмек көрсету арқылы алғашқы жауапкер ретінде әрекет ету қабілеттерін тағы да көрсете білді. Кейбір мысалдарға мыналар жатады:

Үндістандағы Ян Сахас, 20 жастағы қоғамдық ұйым, дағдарысқа 420 000-нан астам мигрантты, сондай-ақ 11000 ЖҚҚ жиынтығын және 17000 мигрант пен олардың отбасыларын жедел тасымалдау арқылы жауап берді.
Бразилиядағы Муда институты кедейлік шегінен төмен тұратын адамдарды жалдайтын қалдықтарды қайта өндеу кооперативтеріне өз жұмысшыларына отбасыларын қолдау үшін ақы төлеуге қаржылай көмек беруге кірісті. Сондай-ақ, оларға қамқорлық көрсетуге, олардың жұмыс жабдықтарымен, бетпердемен, құрал-жабдықтармен және дезинфекциялық гельмен қамтамасыздандырылды.

Harambee Youth employment Accelerator, ол экономикалық тоқтаулардан кейін екі ай ішінде 1,2 миллионнан астам қоңырауды өңдеу үшін Оңтүстік Африка жұмыссыздықтан сақтандыру қорының мүмкіндіктерін кеңейту үшін байланыс орталықтарын ашты [8].

Sevenly әлемдегі өзекті мәселелерге тез жауап береді: мысалы, қазір сіз сайттан тауарлар сатып ала аласыз, оларды сатудан түскен қаражат коронавируспен күресетін дәрігерлер мен жедел жәрдем қызметкерлеріне медициналық маскалар сатып алуға жұмсалады [9].

Сонымен қатар, шетелдік ұйымдардың әлеуметтік кәсіпкерлерге көмек көрсету түрлерін төмендегі кестеден көруге болады (Кесте 1).

Әлеуметтік кәсіпкерлер бүгінгі өзгеріс көшбасшылары ретінде жаңа стандартты ұсынудың ерекше мүмкіндігіне ие. Үкіметтер олармен ынтымақтастық орнатуға және қазіргі уақытта бұрынғыдан да көп өзара тиімді шешімдер табуға тырысады.

Өз рөлін жалғастыру үшін әлеуметтік кәсіпкерлер капиталға және қолдауға тез қол жеткізуді қажет етеді.

Пандемияға қарсы төтенше шараларға бөлінген триллион долларларға қарамастан, олардың аз ғана бөлігі бейресми экономикада қызмет ететін әлеуметтік кәсіпкерлер мен қауымдастықтарға жетеді.

Сондықтан да 2020 жылдың мамыр айында Дүниежүзілік экономикалық форум COVID Response Alliance for Social Entrepreneurship Альянсын құруды ұсынды. Әлеуметтік кәсіпкерлерге арналған Covidке жауап беру альянсын 2020 жылдың сәуірінде 60 жетекші әлеуметтік сектор ұйымдары қолдауды жұмылдыруға және осы кәсіпкерлердің дағдарысты еңсерудегі және одан тыс жерлердегі өмірлік рөлі туралы хабардар болуға көмектесу мақсатында құрды. Альянс мүшелері бүкіл әлем бойынша 50 0000нан астам әлеуметтік кәсіпкерлерді қолдайды. Кәсіпкерлер, өз кезегінде, жұмыспен қамтуға, азық-түлікке, қол жетімді энергияға және басқа да маңызды қызметтерге қол жеткізуді қамтамасыз ете отырып, 1 миллиардқа жуық адамның өміріне тікелей немесе жанама әсер етеді. 
Kесте 1 - COVID эпидемиясы кезінде шетелде әлеуметтік кәсіпкерлікті қолдау

Table 1 - Support for social entrepreneurship abroad during the COVID epidemic

\begin{tabular}{|c|c|}
\hline Компания атауы & Көмек түрі \\
\hline Social Impact Award & $\begin{array}{l}\text { Бұл әлеуметтік кәсіпорындарға жобаны дамытудың алғашқы кезеңдерінде } \\
\text { көмектесетін халықаралық бағдарлама. Мысалы, Ресейде «Моторика» және Сharity } \\
\text { shор түлектер болды. Көктемде ұйым } 16 \text { елде } 100 \text {-ден астам алаңда } 250 \text { семинар } \\
\text { өткізуді жоспарлады. Енді, мүмкіндігінше, іс-шаралар онлайн режимінде өткізіледі, } \\
\text { ал жақын арада өнімдердің көп бөлігі пайдалы вебинарлар болады. Мысалы, ең } \\
\text { бастысы - бір сағаттан аз уақытқа созылатын әлеуметтік кәсіпкерлік туралы шолу } \\
\text { вебинары. Әр түрлі елдер үшін оны жергілікті мамандар жергілікті жағдайлар туралы } \\
\text { айтып, өткізеді. } \\
\text { Сонымен қатар, Канададағы әлеуметтік кәсіпкерлік институтымен және Германия- } \\
\text { дағы Әлеуметтік кәсіпкерлік Академиясымен бірлесіп, жас кәсіпкерлерге әлеуметтік } \\
\text { бизнесті құрудың әртүрлі кезеңдерінде пайдалы болатын білімді қамтитын түрлі } \\
\text { онлайн-құралдар мен оку бағдарламалары ұсынылады. }\end{array}$ \\
\hline Social Enterprise NL & $\begin{array}{l}\text { Негізгі мақсаты Нидерландтың әлеуметтік кәсіпкерлер қауымдастығын құру } \\
\text { болып табылатын Social Enterprise NL ұйымы жергілікті әлеуметтік кәсіпкерлер } \\
\text { қиындықтарға жігерлі жауап беріп, өз шешімдерін ұсына бастағанын атап өтті. } \\
\text { Мысалы, GoodUp ұйымы Corona Care Community платформасын іске қосты, оның } \\
\text { міндеті көмекке мұқтаж адамдарды көмектесе алатын адамдармен байланыстыру } \\
\text { болып табылады. Social Enterprise NL өз кезегінде қауымдастық мүшелерінің } \\
\text { бастамаларын қолдайды, олар туралы өз ресурстарында айтып, әлеуметтік желілерде } \\
\text { өз тәжірибелерімен бөліседі. Олар сонымен қатар қиын кезеңдерде әлеуметтік } \\
\text { кәсіпорындардың тауарларын немесе қызметтерін сатып алуды ынталандыру үшін } \\
\text { \#ыуызосіаlјuіstnu науқанын бастады. }\end{array}$ \\
\hline Social Enterprise UK & $\begin{array}{l}\text { Ұлыбританияның ұлттық әлеуметтік кәсіпкерлер қауымдастығы өз веб - сайтында } \\
\text { коронавирустық індет кезінде бизнесті жүргізудің негізгі мәселелерін қозғайтын } \\
\text { әлеуметтік бизнес үшін ақысыз вебинарлар жариялады-мысалы, жұмыс орындарын } \\
\text { қалай сақтау және бизнестің үздіксіздігін жоспарлау. }\end{array}$ \\
\hline Pioneers Post & $\begin{array}{l}\text { Әлеуметтік кәсіпкерлік туралы Pioneers Post журналы өз сайтында осы қиын- } \\
\text { қыстау уақытта әлеуметтік кәсіпкерлердің істерін, гранттар мен жай ғана пайдалы } \\
\text { сілтемелерді жариялайтын жеке парақ құрды, мысалы, вебинарлар, қаржыландыру, } \\
\text { инвестициялар және ақысыз қолдау бойынша нұсқаулықтар орналастырылған } \\
\text { Covid-19 қайырымдылық ұйымдары мен әлеуметтік кәсіпорындарға арналған } \\
\text { Ресурстық орталықтың ашылуы туралы. }\end{array}$ \\
\hline CASE at Duke & $\begin{array}{l}\text { АҚШ-тағы Дьюк университетінің әлеуметтік кәсіпкерлікті дамыту орталығы әлемнің } \\
\text { кез-келген нүктесінде әлеуметтік кәсіпкерлер мен коммерциялық емес ұйымдардың } \\
\text { назарын аударуға көмектесетін гранттар мен несиелер туралы ақпарат жинайтын } \\
\text { ауқымды мәліметтер базасын құрды. }\end{array}$ \\
\hline
\end{tabular}

Бүгінгі таңда Альянс өзінің мүшелері қабылдаған іс-әрекеттерге негізделген және оларды жаңа міндеттемелерге шабыттандыруға бағытталған COVID әлеуметтік кәсіпкерлік іс-қимыл бағдарламасын шығарады [11].

Impact Hub Moscow әлеуметтік инновацияларды қолдау орталығы Санкт-Петербург мемлекеттік университетінің мен Массачусетс университетінің Жоғары менеджмент мектебінің ғалымдарымен бірлесіп, 2020 жылдың маусымынан 2021 жылдың қаңтарына дейін әлеуметтік кәсіпкерлікке арналған зерттеулер жүргізді. Оның мақсаты - Covid-19 пандемиясы кезінде осы салада болған өзгерістерді анықтау. Зерттеушілер ұйымдарға дағдарысты жеңуге көмектесетін инновациялар мен стратегияларға ерекше назар аударды.
Зерттеуге қатысқан ресейлік әлеуметтік кәсіпорындардың көпшілігі шағын бизнес $(12 \%)$ және микробизнес (82\%) болып табылады. Компаниялардың жалпы жасы бес - алты жылды құрайды, сонымен қатар пандемия басталған кезде олар даму және өсу кезеңдерінде болды.

«Пандемия дәуіріндегі әлеуметтік кәсіпкерлік» зерттеуі мамандарға бірнеше негізгі тенденцияларды анықтауға мүмкіндік берді.

- Пандемия ұйымдардың географиялық кеңеюінде маңызды рөл атқарды, бұл туралы респонденттердің $50 \%$ хабарлады. Бірден бірнеше өңірде жұмыс істейтін әлеуметтік кәсіпкерлер саны 50\% - ға өсті. Респонденттердің көпшілігінің пікірінше, мұндай өсуге онлайн-жұмыс форматы әсер етті. 
- Пандемия кезінде сұранысқа ие стратегиялар компаниялардың тиімділігін арттыруға бағытталған болатын. Респонденттердің 89\%-ы қолданыстағы өнімдерді жақсарту үшін жұмыс істеді, кәсіпкерлердің 87\%-ы жаңа өнімдерді жасау үшін жұмыс істеді. Деректер сондай-ақ кәсіпорындардың 87\%-ы бизнес-процестерді оңтайландырғанын, 86\%-ы қызметкерлердің құзыретін арттыруға шоғырланғанын, 83\%-ы жаңа серіктестерді тартқанын көрсетеді.

- Пандемия онлайн-сатылымдардың дамуына әсер етті. Ұйымдар қолданыстағы өнімдердің сандық нұсқаларын іске қосты (46\%) және диджитал-форматтағы (47\%) жаңа тауарлар мен қызметтерді құруды іске асыра бастады.

- Пандемия жалпы енгізіліп жатқан инновациялардың санын көбейтті. Әлеуметтік кәсіпкерлердің 53\% - ы өз компаниялары үшін және жалпы нарық үшін жаңашыл болып табылатын өнімдерді ұсынды.

- COVID-19 туындаған қиындықтарға қарамастан, әлеуметтік кәсіпкерлер позитивті болуға тырысады. Зерттеу аясында респонденттердің 50\% - ы өздерінің ұйымдары тіпті коронакризисте де пайда әкелетінін айтты. Қатысушылардың 64\%-ы пандемия бизнесті қайта құруға мүмкіндік бергеніне сенімді.

Зерттеу авторларының бірі және СанктПетербург мемлекеттік университетінің академиялық директоры Юлия Арайдың айтуынша, әлеуметтік кәсіпкерлер COVID-19 туындаған қиындықтарға төтеп бере алды. Ол сектордың мамандары бенефициарлар алдындағы жауапкершілікті және жаңа шешімдер табуға көмектесетін кәсіпкерлік рухты басқаратынына сенімді. «Әлеуметтік кәсіпкерлер жұмыс істеген жылдар ішінде ресурстар мен құзыреттерді жинақтап, олардың бір бөлігін «коронакризис» кезінде пайдалана бастады. Ол көптеген адамдарды бұрыннан ойлаған істі жасауға итермелеген. Сондықтан пандемия-баға жетпес тәжірибе уақыты екенін түсіну керек. Бұл тәжірибені ұмытпау және одан әрі қарай жүру маңызды», - деп санайды Юлия Арай.

Сектор, әрине, оң қарқынмен дамып келеді, бірақ әлеуметтік кәсіпкерлердің қажеттіліктеріне сәйкес қолдау шараларын кеңейту қажеттілігі кеміген жоқ. Пандемия кезінде сала өкілдерінің 72\% - ы менторлар мен тәлімгерлерге жүгінді. Респонденттердің $74 \%$ - ы білім беру бағдарламаларымен жұмыс істеді, 75\% - ы мамандандырылған іс-шаралар өткізді: вебинарлар, дәрістер, семинарлар. Респонденттердің көпшілігінің айтуынша, қолдаудың барлық түрлері өте пайдалы болды [12].
Қазір бүкіл әлем коронавирус пандемиясымен қамтылып, Қазақстанда да күрделі жағдай қалыптасып, ел экономикасы мен халықтың денсаулығына елеулі қауіп төніп тұр. Ел Президенті мұндай жағдайға қазақстандықтар тәуелсіздіктің тоқсаныншы жылдарында да, ең басында да тап болмағанын атап өтті.

Қазіргі уақытта Қазақстан «жасанды» экономикалық комаға түсіп отыр. Бүгінде шағын және орта бизнес мемлекеттің экономикалық әл-ауқатына тікелей әсер етеді, өйткені халықты жұмыспен қамту проблемаларын шешу, ішкі нарықты отандық тауарлармен толтыру және бәсекелестік ортаны қалыптастыру көбіне соған байланысты. Тұрақсыз жағдай бүкіл елдің экономикасына және оның негізгі қатысушылары - шағын және орта бизнес объектілеріне әсер етеді.

Сауда, туризм және қоғамдық тамақтану салаларындағы ШОБ субъектілері жоғары тәуекел аймағына тап болды. Бұл секторларда 1,6 миллионнан астам жұмысшы жұмыс істейді. Карантинді енгізу жастардың өңірлерге кетуіне себеп болды. Бұл студенттер, базарлардың, қызмет көрсету, сауда ұйымдарының қызметкерлері.

11,5 мыңнан астам шағын және орта бизнес субъектілері жалпы сомасы 360 миллиард теңгеден астам (бұл шамамен 62 миллиард рубль) қарыздар мен кредиттер төлеу бойынша мерзімін кейінге қалдырды. 200 миллиард теңге (шамамен 35 миллиард рубль) көктемгі егіс жұмыстарын қаржыландыруға бағытталған. Жалпы, азаматтар мен бизнесті қолдауға бағытталған қаражат көлемі 6 триллион теңгеге жетті (шамамен 1 триллион рубль) [13].

«Жарқыра» әлеуметтік кәсіпкерлері карантинге қарамастан, қалаға COVID19-мен күресуге көмектесе отырып, жұмысын онлайн форматта жалғастырды. Бағдарламаның төрт финалисті-Арайлым Нұғманова, Гүлбарам Ермұханова, Мира Есниязова және Айгүл Уәлиева - еріктілер болып, пандемияның ең қиын кезеңдерінде клиникалар мен қала тұрғындарына көмек көрсетті.

Сондай-ақ, құрылтайда қазіргі уақытта әлеуметтік кәсіпкерлік туралы заң бойынша жұмыс жүргізіліп жатқаны туралы айтылды, оны қабылдау 2021 жылға жоспарланған. Депутаттарға коммерциялық емес сектор сарапшыларының жұмыс тобы көмектесуде, оның құрамына ОАЕҚ өкілдері мен «Жарқыра»бағдарламасына қатысушылар да кіреді. ОАЕҚ БК қолдау саласындағы өзінің жұмыс тәжірибесін ұсынды, әлеуметтік кәсіпкерліктің анықтамасы мен критерий- 
леріне ұсыныстар енгізді, экономиканың жаңа секторын мемлекеттік қолдау шараларын ұсынды [14].

Қазақстанда әлеуметтік кәсіпкерліктің анықтамасы әлі бекітілген жоқ, әлеуметтік кәсіпкерлік туралы заң да жоқ. Бірақ әлеуметтік кәсіпкерлерді анықтау мен қолдауға қоғамдық ұйымдар, соның ішінде халықаралық ұйымдар да, мемлекеттік құрылымдар да назар аударды. Мысалы, 2019 жылы ҚР АКДМ Impact Hub Almaty Корпоративтік қорымен бірлесіп Бірінші Республикалық Ozgeris Ustasy сыйлығын өткізді. Оның 15 жеңімпазы 500 мың теңгеге грант алды, сонымен қатар Қазақстанның әлеуметтік кәсіпкерлерінің тізілімі қалыптастырылды, әзірше оған елдің 152 әлеуметтік кәсіпкері кірді. Осы тізілім негізінде әлеуметтік кәсіпкерлердің көпшілігі (40\% - дан сәл артық) «осал топтарға көмек/ қолдау» сегментінде, көлемі бойынша екінші сегмент - «білім» $(14,85 \%)$ сегментінде шоғырланғанын көруге болады. Әлеуметтік кәсіпкерлердің 43,4\% - ы өз қызметін бес жылдан астам уақыт бойы жүргізіп келеді, ал бұл мәселеде ең белсенді өңірлер-Түркістан облысы (Әлеуметтік кәсіпкерлер тізіліміне енгендердің 22\% - ы сонда орналасқан), НұрСұлтан (19\%), содан кейін ғана-Алматы (7\%) [15].

АКДМ азаматтық қоғам істері комитеті төрағасының орынбасары Гүлбара Сұлтанова Қазақстанда әлеуметтік кәсіпкерліктің алғашқы өскіндері 2000-шы жылдардың ортасында тиісті ҮЕҰ пайда болуымен байқалғанын, екінші толқын 2010 жылы, осы бағытта ірі бизнес пен түрлі қорлар жандана бастағанын атап өтті.

- Қазір үшінші толқын келе жатыр, тақырып Сенатта белсенді түрде қолдау табуда. Әлеуметтік кәсіпкерлік үлкен экономикалық әлеуетке ие, сонымен қатар азаматтық сектордың бәсекеге қабілеттілігінің көздерінің бірі болып табылады. Мәселелер 3 ведомствоның: Еңбек және әлеуметтік қорғау министрлігінің, Ұлттық экономика және АҚДМ - нің назарында, - деп атап өтті ол конференцияда [16].

Жақында еңбек және әлеуметтік қорғау министрінің кеңесшісі болып тағайындалған және әлеуметтік кәсіпкерлік жөніндегі заң жобасын әзірлеу жөніндегі жұмыс тобына кірген әлеуметтік кәсіпкер Эмин Аскеров осы мәселе бойынша республикадағы алғашқы Талдамалық зерттеудің қорытындыларын ұсынды.

- Қазір Қазақстанда 300-ге жуық әлеуметтік кәсіпкер жұмыс істейді. Біз 29 сұрақ бойынша 297 респондентпен сұхбаттасып, көптеген қайғылы сәттерді анықтадық. Оның ішінде осы бағыттың даму серпіні төмен.

22 әлеуметтік кәсіпкер олардың жобалары карантин мен онымен байланысты шектеулерге (әлеуметтік кәсіпорындардың 25 пайыздан астамы COVID-19 салдарынан жойылды), қол жетімді баспаналардың болмауына, қаржылық проблемаларға, осы мәселенің заңнамалық реттелмеуіне, бюрократияға және басқа да себептерге байланысты жабылуда екенін атап өтті, - деді Эмин Әскеров [16].

Әлеуметтік кәсіпкерліктің 7,4\%-ы қазіргі таңда жабылу деңгейінде және жабылу себептері төмендегі диаграммада көрсетілген (Сурет 1).

Сонымен бірге, қоғам коронавируспен күресу үшін бюджет ақшасының көп жұмсалуына алаңдайды. 2019 жылдың шілде айында БАҚ хабарлағандай, денсаулық сақтау министрлігіне Қазақстандағы коронавируспен күреске 114 миллиард 826 миллион теңге бөлінді. Бұл соманың 40,5 миллиарды Үкіметтің резервінен бөлінді. Оның 21,1 миллиарды - жеке қорғану құралдарын сатып алуға, 2,03 миллиарды - дәрілік заттар мен медициналық бұйымдарды сатып алуға жұмсалды. Тағы 2,5 миллиард - зертханалық жабдықтар мен коронавирусты анықтайтын жүйелер сатып алуға. Алайда, Денсаулық сақтау министрлігінің ресми өкілі Бағдат Қожахметовтың 11 қыркүйектегі ақпараты бойынша, Қазақстан « көру қабілетіне қарсы іс-шараларға « 102,8 миллиард теңге жұмсады.

«Коронавирус үлкен шығындарға қарамастан, бізде індетке қарсы күресте жетістіктер нөлдік деңгейде екенін көрсетті. Қазақстан жан басына шаққанда Қырғызстаннан 20 есе көп қаражат жұмсады. Сонымен қатар, олардың жан басына шаққанда жұқтырған дәрігерлері үш есе аз. Вирус жұқтырған дәрігерлер коронавирустық инфекциямен күресудің сәтті көрсеткіштерінің бірі болып табылады. Ковид келді, адамдар ауруханаға жете алмаған кезде бүкіл денсаулық сақтау жүйесі сал болды», - деп еске алады Конеев.

Әлеуметтік кәсіпкерлер үшін негізгі проблема-коронавирустық пандемияға байланысты карантин. Осы 7,4\% респонденттердің шамамен 2\%-ы карантин мен жалғасып жатқан шектеулерге байланысты оларды жабуға мәжбүр болды деп жауап берді.

Респонденттердің басқа жауаптары барлық басқа негізгі проблемалар бойынша біркелкі бөлінеді: шикізат сапасының төмендігі, өндірістік кеңістіктің жоқтығы, қаржылық проблемалар, басқа аймаққа көшу, өндірілген өнімді немесе көрсетілетін қызметті сату мүмкіндігінің болмауы. 


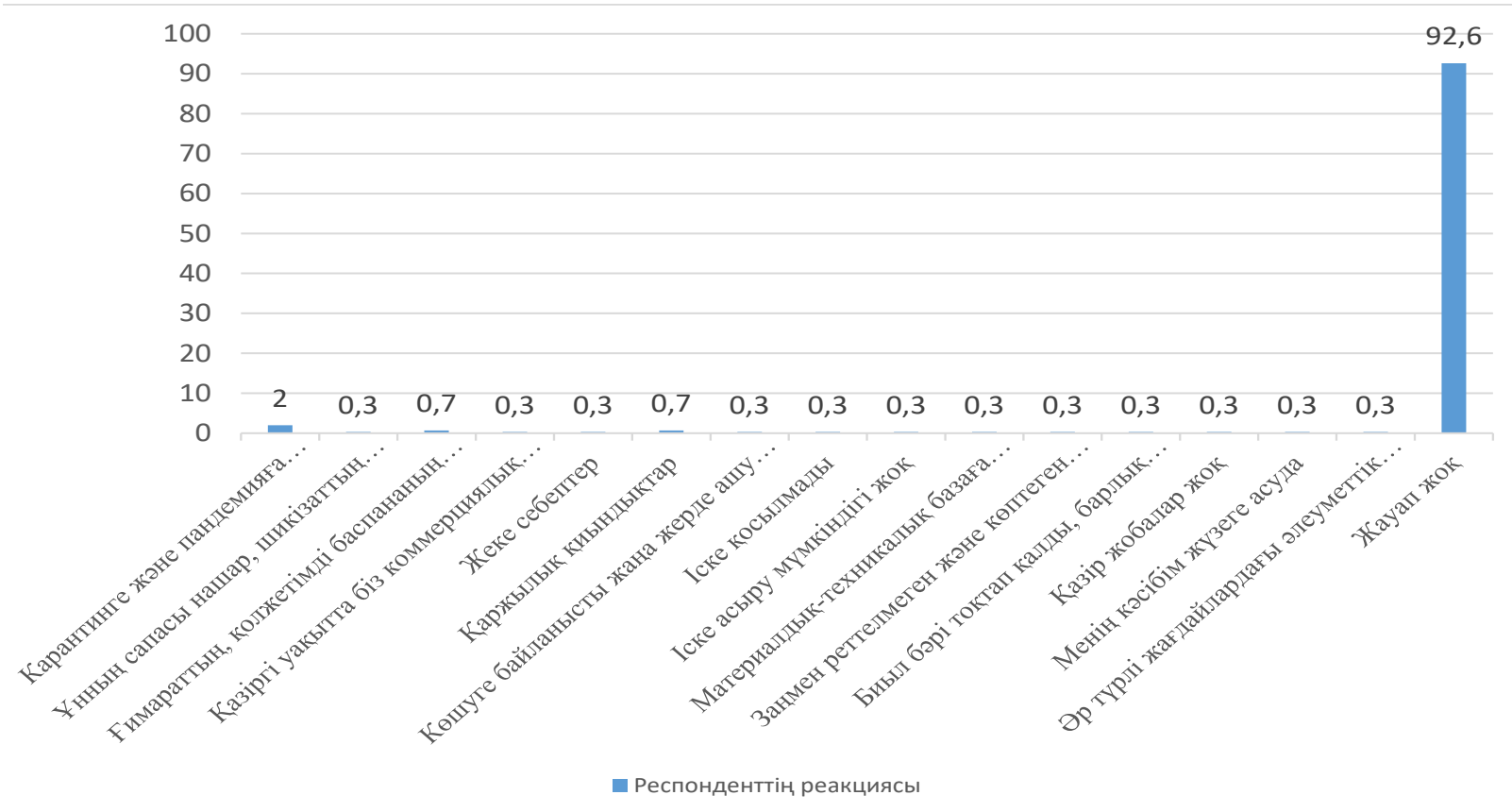

Сурет 1 - Әлеуметтік кәсіпкерліктің жабылу себептері [17]

Figure 1 - Reasons for the closure of Social Entrepreneurship [17]

Осылайша, әлеуметтік бизнестің жойылуының 25\%-дан астамы дәл COVID-19 пандемиясының салдарынан болды деп айта аламыз.

Осыдан кейін ғана сарапшының айтуынша, алдымен Қазақстан президенті Қасым-Жомарт Тоқаев, содан кейін сыбайлас жемқорлыққа қарсы қызмет денсаулық сақтау саласын тексеру қажеттігіне назар аударды. Сұхбаттасушы Денсаулық сақтау министрлігі жүйесінде сыбайлас жемқорлық учаскелері бар екенін айтады. Оларға тауарлар мен қызметтердің сапасы мен қауіпсіздігін бақылауға жауап беретін салалар (олардың ішінде санэпидқадағалау), дәрі-дәрмектерді сатып алу, сараптау және бақылау, сондайақ денсаулық сақтау жүйесін цифрландыруға жауап беретін бөлімдер кіреді [18].

Сыбайлас жемқорлық және қызмет бабын жеке мақсатта теріс пайдалану-бұл жай ғана ақшаны ысырап ету емес: мұндай құбылыстар қоғамдық Шарттың қолданыстағы тетіктерін бұзады және мемлекеттің барлық азаматтардың игілігі үшін экономикалық өсуді қамтамасыз ету қабілетіне теріс әсер етеді. Әлемдік экономикадағы ағымдағы дағдарыстық жағдай сыбайлас жемқорлыққа қарсы қатаң саясатты іске асыру туралы мәселенің маңыздылығын арттырды.

Ағымдағы жағдайларда сыбайлас жемқорлыққа қарсы тиімді шаралар рөлінің артуы бірнеше факторларға байланысты. Біріншіден, дағдарыстық жағдай мемлекеттік аппараттан көп күш-жігерді талап етеді және мемлекеттік органдар мен олардың қызметкерлерінің өсіп келе жатқан өкілеттіктері қазіргі жағдайда сыбайлас жемқорлықтың көріну мүмкіндіктерін арттырады. Екіншіден, мемлекеттік қаржыландырудың жетіспеушілігі жағдайында елдер салық төлемеу және бюджет қаражатын ысырап ету жағдайларының алдын алуы қажет. Сондай-ақ, дағдарыстық жағдай мемлекеттік институттар мен оларға сәйкес механизмдер өтетін адамдардың сенімін тексерудің бір түрі екенін атап өткен жөн [19].

\section{Қорытынды}

Қазіргі жағдайда әлеуметтік кәсіпкерлікке сұраныс күрт артып келеді. Көптеген дәстүрлі кәсіпкерлер әлеуметтік сипатқа ие болады, мүмкін олардың кейбіреулері дағдарыстан кейінгі қызметінде осындай компонентті қалдырады [20].

Біріншіден, әлеуметтік кәсіпкерлер үкімет істей алатын немесе қаламайтын нарықтағы олқылықтарды жоюға және осал топтаға халықты қамтуға жақсы мүмкіндіктерге ие. Бұл пандемиядан экономикалық немесе әлеуметтік тұрғыдан аз қамтылған қауымдастықтар қатты зардап шегеді; бірақ сол қолайсыз жағдай мемлекеттік көмек пен қызметтердің енуін қиындатады, бұл әлеуметтік кәсіпорындарды одан да маңызды етеді. Root Capital ұйымы Африка, Латын Америкасы және Индонезияның ең шалғай қауымдастықтарында жұмыс істейді. Жаһан- 
дық желі бойынша әлеуметтік бағдарланған кәсіпорындармен жұмыс жасай отырып, соңғы бірнеше ай ішінде олар жүздеген мың ауылдық отбасыларға қызметтер мен қажетті тауарларды (бет маскалары, сабын, дәрідәрмектер және басқалар) ұсына алды. Сол сияқты, Амазонканың табиғатты қорғау тобы Амазонканың өте алыс байырғы қауымдастықтарындағы қоғамдық қызметтердің вакуумын толтырады. Сонымен қатар, олар Денсаулық сақтау туралы ақпаратты ана тілдеріне аударады және оны жергілікті қауымдастықтар қолданатын радио және WhatsApp арналары арқылы бөліседі. Әлеуметтік кәсіпкерлер жеткілікті қызмет көрсетілмеген топтарды қамтуға дайын, қабілетті және қалайды - көптеген жағдайларда олар осы қауымдастықтарға қол жеткізе алады. Осы байланыстарды қолдана отырып, әлеуметтік кәсіпкерлер осы пандемияның пропорционалды емес салдарын жоюға көмектеседі.

Екіншіден, әлеуметтік кәсіпкерлер пандемияның екінші және үшінші мәселелерін шеше алады. Үкіметтер Денсаулық сақтау мен экономикадағы ең ауыр күйзелістерді жеңілдетуге күш салса да, әлеуметтік кәсіпкерлер жұмыспен қамтудан бастап білімге дейінгі барлық каскадтық Салдарлар үшін инновациялық шешімдер ойлап табуы мүмкін. Мысалы, YouthBuild USA жүйелік мәселені шешеді: Америкада 16-24 жас аралығындағы 4,5 миллион жас, тіпті covid-19 пайда болғанға дейін де жұмыста да, мектепте де болған жоқ. Осы жылдың ақпан-маусым айлары аралығында «ажыратылған» жастардың (жұмыссыз және мектепке бармайтын) үлесі екі еседен астам өсті, бұл YouthBuild жұмысын одан да маңызды етті. YouthBuild USA президенті және бас директоры Джон Вальверденің айтуынша, 2008 жылы Ұлы Рецессия кезінде мектепті бітірген жастар «Covid-19 соққан кезде қалпына келе бастады». Енді, дейді Вальверде, «олар одан әрі артта қалып қана қоймайды, сонымен қатар 2020 жылы мектепті бітірген жастар да осындай салдарға ұшырайды, егер нашар болмаса. Сондықтан YouthBuild біздің моделімізді тек жұмыс орындары мен дағдыларды құруға ғана емес, сонымен бірге студенттеріміздің психикалық денсаулығы мен әл-ауқатына және жастарға Covid-19 дауылынан аман өтуге көмектесетін берік әлеуметтік байланыстар жасауға бағыттады."”

Сонымен, ең бастысы, әлеуметтік кәсіпкерлер бізге Covid-19-дан кейін жақсы қалпына келтіруге көмектеседі. Біздің жетекшілеріміздің көпшілігі ұзақ мерзімді мәселелерді шешуге емес, өртті сөндіруге бағыт- талған. Әлеуметтік кәсіпкерлер бұзылған жүйелерді өзгертуге жеткілікті төзімділікке ие. Пандемия басталғанға дейін олар жүйелік мәселелерді шешіп үлгерді - жоғарыда айтылғандар ғана емес, сонымен қатар соңғы айларда пайда болған басқа да мәселелер: нәсілдік әділеттілік, гендерлік теңдік, жауапты жеткізілім тізбегі, қол жетімді Денсаулық сақтау, қаржылық қол жетімділік және басқалар. Бұл проблемалар Covid-19 сияқты дағдарыстармен күрделене түседі. Мысалы, БҰҰ-ның Тұрақты даму мақсаттары сияқты ұзақ мерзімді мақсаттарға қазір қауіп төніп тұрғанын білеміз. Пандемия 100 миллион адамды төтенше кедейлікке итермеледі, ал 132 миллион адам қатты аштыққа тап болады деп болжануда.

Әлеуметтік кәсіпкерлікті қаржыландыру тапшылығының нақты мөлшерін бағалау қиын, бірақ біз оның маңызды екенін білеміз, әсіресе созылмалы қаржыландырылмаған қауымдастықтарда (АҚШ-та да, шетелде де). Басқа коммерциялық және коммерциялық емес ұйымдар сияқты, әлеуметтік кәсіпорындар да covid-19 пандемиясына байланысты қаржылық қауіптің жоғарылауына тап болады. Бірақ біздің қазіргі дағдарысымызбен шиеленіскен бірқатар проблемаларға ықтимал әсер етуді ескере отырып, капиталды жеткізушілер әлеуметтік кәсіпкерлерге, әсіресе табысы төмен елдер мен қауымдастықтарға қолдау көрсетуді арттыруы керек. Бұл бастапқы инвестициялар трансформациялық өзгерістердің әлеуетін толығымен ақтайды. Қолдау арқылы әлеуметтік кәсіпкерлер қазіргі дағдарысты жеңуге ғана емес, сонымен бірге жақсы әлем құруға да көмектесе алады [21].

Коронавирусты қайта құру жоспарларын әзірлеу кезінде Мұхаммед Юнус Жаңа бизнес-модельдің басты рөлін - әлеуметтік кәсіпкерлікке беруді ұсынады. Мұндай бизнес-модель инвестицияланған қаражатты қайтарудан басқа, инвесторлардың жеке пайдасынсыз адамдарға өз проблемаларын шешуге көмектесудің жалғыз мақсатымен жасалады. Барлық инвестицияланған қаражат қайтарылғаннан кейін барлық пайда бизнесте қалады.

Бүгінгі таңда мемлекеттер экономиканы қайта құруға әлеуметтік бағдарланған кәсіпорындардың қатысуын ынталандыруға және оларға осы мәселеде басты рөл атқаруға мүмкіндік алды. Алайда, үкіметтер сол кезде және экономиканың ең қажет секторында әлеуметтік бизнестің пайда болуын күтпеуі керек. Мемлекеттер тұрмысы төмен және жұмыссыздарға көмек көрсетудің дәстүрлі бағдарламаларынан, денсаулық сақтауды 
қолдау және өзге де әлеуметтік маңызы бар салаларды қалпына келтіру бағдарламаларынан, сондай-ақ әлеуметтік бизнес-модельдері баяу дамып келе жатқан нарық секторларындағы ұйымдардың барлық түрлерін қолдаудан бас тартпауға тиіс.

Әлеуметтік бағдарланған компанияларды тарту мақсатында мемлекет әлеуметтік бизнесті қолдаудың венчурлік инвестициялық қорларын (Social Business Venture Capital Funds) орталықтан да, сол сияқты жергілікті жерлерде де құра алады не жеке сектор, қайырымдылық және инвестициялық қорлар, қаржы ұйымдары ортасында осындай инвестициялық қорлардың құрылуын көтермелей алады. Мемлекет компаниялардың дәстүрлі бизнес-модельдерден қоғамға бағдарланған модельдерге көшуіне ықпал ете алады және әлеуметтік кәсіпорындармен әріптестік қатынастарды дамытуды қолдай алады. Бұдан басқа, мемлекет қазірдің өзінде жұмыс істеп тұрған компаниялар құрылымында жаңа әлеуметтік бағыттар құруды және әлеуметтік бизнес өкілдерімен бірлесіп, венчурлік әлеуметтік жобаларды дамытуды көтермелей алады.

Экономиканы қайта құру арқылы мемлекет әлеуметтік бағдарланған ұйымдарға компанияларды сатып алуға және мұқтаж коммерциялық компанияларды қоғамға бағдарланған компанияларға айналдыруға қаражат бере алады. Орталық банк осындай компанияларға, басқалар сияқты, қор нарықтарына инвестициялау үшін несие ұйымдарынан қаржыландыру алуға рұқсат бере алады.

Экономиканы қалпына келтіру процесінде көптеген жаңа мүмкіндіктер пайда болады және мемлекеттің міндеті - бұл процеске мүмкіндігінше әлеуметтік бағдарланған ұйымдарды тарту.

Әлеуметтік кәсіпкерлер мен инвесторлар мемлекеттің назары мен қолдауына ие бола отырып, олардан Қазіргі тарихи сәт талап ететін маңызды рөл атқара алады. Әлеуметтік кәсіпкерлерді ізгіліктердің шағын тобы ретінде қарастыруға болмайды. Олар ірі халықаралық ұйымдарды, әлеуметтік бизнесті қолдаудың үлкен қорларын, көптеген талантты менеджерлерді, ықпалды корпоративті ұйымдарды, қайырымдылық қорларын, Ғаламдық және жергілікті әлеуметтік бизнес жобаларын қаржыландыру мен басқаруда көп жылдық тәжірибесі бар сенімді басқарушыларды қамтитын Елеулі жаһандық экожүйені білдіреді.
Әлеуметтік кәсіпкерлік саласындағы тұжырымдама мен жинақталған тәжірибе мемлекеттің назарына айналғаннан кейін, көптеген жеке байытуды іздеушілер өздерінің таланттарының күтпеген жақтарын көрсете алады және әлеуметтік бағдарланған жобалар саласында табысты кәсіпкер бола алады және климаттық өзгерістерге, жоғары жұмыссыздыққа, материалдық тауарлардың біркелкі бөлінбеуіне және басқа да проблемаларға байланысты әлеуметтік-экономикалық дағдарыстар кезеңінде маңызды рөл атқарады.

Әлеуметтік бизнес қазірдің өзінде шеше алатын мәселелердің бірі-экономикалық күйреуден туындаған жұмыссыздық мәселесі. Әлеуметтік инвесторлар жұмыссыздарға жұмыс орындарын құруға ақша жұмсай алады. Сонымен қатар, олар жұмыссыздарға өз бизнестерін кәсіпкерлерге айналдыру арқылы бастауға көмектесе алады, осылайша адамға жұмыс іздеуші емес, кәсіпкер болып туылғанын дәлелдейді. Мемлекетпен ынтымақтастықта әлеуметтік кәсіпкерлер денсаулық сақтаудың сенімді жүйесін құра алар еді [22].

\section{Пайдаланылган ддебиеттер тізімі}

1. Jay Boolkin (2020). The impact of coronavirus on social entrepreneurs and changemakers. Social Good Stuff 2020 [Электронды pecypc]. URL: http://socialgoodstuff.com/2020/05/the-impactof-coronavirus-on-social-entrepreneurs-andchangemakers/ (дата обращения: 04.06.2020)

2. British Council Казахстан (2020). I-SEED: Социальное предпринимательство и образование // [Электронды pecypc] URL: https://kazakhstan. britishcouncil.org/ru/i-seed/faqs) (дата обращения: 04.06.2020)

3. World Economic Forum 91-93 route de la Capite (2020). Who are social entrepreneurs? COVID-19 Action Agenda, September, 41.

4. Drayton, William (2002). The Citizen Sector: Becoming as Entrepreneurial and Competitive as Business. California, In: California Management Review, 44 (3), 120-132 .

5. Edwards, Michael (2010). Small Change: Why Business Won't Save the World. San Francisco, BerrettKoehler, 56.

6. Cabinet Office (2007). Social Enterprise Action Plan: Scaling New Heights. London, Office of The Third Sector, 142.

7. Nicholls, Alex (2008). Capturing the Performance of the Socially Entrepreneurial Organization (SEO): An Organizational Legitimacy Approach. In: Robinson, Jeffrey/ Mair, Johanna/ Hockerts, Kai (Eds.): International Perspectives on Social Entrepreneurship Research. London, Palgrave Macmillan, 89. 
8. Members of the COVID Response Alliance for Social Entrepreneurship (2020). Why social entrepreneurs are vital to the COVID-19 crisis. World Economic Forum. [Электронды ресурс]. URL: https:// news.trust.org/item/20200916150609-umtkl/ (дата обращения: 04.06.2020)

9. Пикулёва Е. (2020). Sevenly: вещи, которые меняют мир. Новый бизнес. Социальное предпринимательство. [Электронды ресурс]. URL: http://nb-forum.ru/foreign-experience/sevenly-veschikotorie-menyayut-mir (дата обращения: 04.06.2020)

10.Пикулёва Е. (2020). Поддержка СП за рубежом во время эпидемии COVID. Новый бизнес. Социальное предпринимательство. [Электронды pecypc]. URL: http://nb-forum.ru/foreign-experience/ podderzhka-sp-za-rubezhom-vo-vremya-epidemiicovid (дата обращения: 04.06.2020)

11. World Economic Forum 91-93 route de la Capite (2020). Why Social Entrepreneurs Are Needed Now More than Ever? COVID-19 Action Agenda, September, 9 .

12.Башурина Е. (2021). «Пандемия — время бесценного опыта»: как переносят «коронакризис» российские социальные организации. FORBES 2021 [Электронды ресурс]. URL: https://www.forbes.ru/ forbeslife/424309-pandemiya-vremya-bescennogoopyta-kak-perenosyat-koronakrizis-rossiyskiesocialnye (дата обращения: 04.06.2020)

13. Амангельдинова С.Е., Протасова О.В., Горковенко Л.А. (2020) Казахстан в новых жизненных реалиях в период пандемии коронавируса. Инновационная экономика: перспективы развития и совершенствования, 3 (45).

14.Курултай социальных предпринимателей программы «Жаркыра» (2020). ФОНД ЕВРАЗИЯ ЦЕНТРАЛЬНОЙ АЗИИ В КАЗАХСТАНЕ. [Электронды ресурс] URL: http://www.ef-ca.kz/news/fond/kurultay socialnyh predprinimate (дата обращения: 04.06.2020)

15.Бапиев К. (2020). Как в Казахстане развивается социальное предпринимательство. Курсив. [Электронды ресурс]. URL: https://kursiv.kz/ news/biznes/2020-02/kak-v-kazakhstane-razvivaetsyasocialnoe-predprinimatelstvo (дата обращения: 04.06.2020)

16.Абжекенова Н. (2020). Что такое социальное предпринимательство и с какими проблемами сталкиваются игроки этого поля в Казахстане. Караван. [Электронды ресурс]. URL: https://www.caravan.kz/articles/chtotakoe-socialnoe-predprinimatelstvo-i-s-kakimiproblemami-stalkivayutsya-igroki-ehtogo-polya-vkazakhstane-687880/ (дата обращения: 04.06.2020)

17.Информационно - аналитический отчет СП Аскерова Э.Х. (2020). В рамках комплексного социального исследования «Социальное предпринимательство в Казахстане. Проблематика и пути развития» Нур-Султан, 2020.

18.Асылбек Б. (2020). «Кланы взяли лакомые кусочки и тихо сели на госзаказ». Что не так с кадровой системой Минздрава. Радио Азаттык 2020 [Электронды pecypc]. URL: https://rus. azattyq.org/a/corruption-in-the-health-care-system- in kazakhstan/30917536.html (дата обращения: 04.06.2020)

19. Vitor Gaspar, Martin Mühleisen, Rhoda Weeks-Brown. (2020). Коррупция и пандемия COVID-19. Росконгресс 2020 [Электронды ресурс]. URL: https://roscongress.org/materials/korruptsiya-ipandemiya-covid-19/ (дата обращения: 04.06.2020)

20.Андреева О.В., Капцова В.С. (2019). Развитие идей социального предпринимательства - актуальное направление научных исследований. Вопросы формирования и проблемы реализации национальной технологической инициативы в регионах: сборник докладов участников I международной научно-практической конференции 2019. 258-261.

21. W. Foote. (2020). How Social Entrepreneurs Will Help Us Fight Covid-19 And Build Back Better. Forbes 2020 [Электронды ресурc]. URL: https://www. forbes.com/sites/willyfoote/2020/11/17/how-socialentrepreneurs-will-help-us-fight-covid-19-and-buildback-better/?sh=63baaf615c93 (дата обращения: 04.06.2020)

22. ТПП РФ. (2020). Программа посткоронавирусной реконструкции. Нет пути назад. Капитал страны. [Электронды ресурс]. URL: https://kapital-rus.ru/uznai/news/programma postkoronavirusnoj_rekonstrukcii_net_puti_nazad_/ (дата обращения: $0 \overline{4} .06 .2020$ )

\section{References:}

1. Jay Boolkin (2020). The impact of coronavirus on social entrepreneurs and changemakers. Social Good Stuff. [Elektronnyj resurs]. URL: http://socialgoodstuff. com/2020/05/the-impact-of-coronavirus-on-socialentrepreneurs-and-changemakers/ (Data obrashcheniya: 04.06.2020)

2. British Council Kazahstan (2020). I-SEED: Social'noe predprinimatel'stvo i obrazovanie. [Elektronnyj resurs] URL: https://kazakhstan. britishcouncil.org/ru/i-seed/faqs) (Data obrashcheniya: 04.06.2020)

3. World Economic Forum 91-93 route de la Capite (2020). Who are social entrepreneurs? COVID-19 Action Agenda, September 2020, 41.

4. Drayton, William (2002). The Citizen Sector: Becoming as Entrepreneurial and Competitive as Business. California, In: California Management Review, 44 (3), 120-132.

5. Edwards, Michael (2010). Small Change: Why Business Won't Save the World. San Francisco, BerrettKoehler, 56.

6. Cabinet Office (2007). Social Enterprise Action Plan: Scaling New Heights. London, Office of The Third Sector, 142.

7. Nicholls, Alex (2008). Capturing the Performance of the Socially Entrepreneurial Organization (SEO): An Organizational Legitimacy Approach. In: Robinson, Jeffrey/ Mair, Johannal Hockerts, Kai (Eds.): International Perspectives on Social Entrepreneurship Research. London, Palgrave Macmillan, 89. 
8. Members of the COVID Response Alliance for Social Entrepreneurship (2020). Why social entrepreneurs are vital to the COVID-19 crisis. World Economic Forum. [Elektronnyj resurs]. URL: https:// news.trust.org/item/20200916150609-umtkl/. (Data obrashcheniya: 04.06.2020)

9. Pikuljova, E. (2020). Sevenly: veshhi, kotorye menjajut mir. Новый бизнес. Социальное предпринимательство 2020 [Elektronnyj resurs]. URL: http://nb-forum.ru/foreign-experience/sevenlyveschi-kotorie-menyayut-mir (Data obrashcheniya: 04.06.2020)

10.Pikuljova E. (2020). Podderzhka SP za rubezhom vo vremja jepidemii COVID. Novyj biznes. Social'noe predprinimatel'stvo 2020 [Elektronnyj resurs]. URL: http://nb-forum.ru/foreign-experience/ podderzhka-sp-za-rubezhom-vo-vremya-epidemiicovid (Data obrashcheniya: 04.06.2020)

11. World Economic Forum 91-93 route de la Capite (2020). Why Social Entrepreneurs Are Needed Now More than Ever? COVID-19 Action Agenda, September 2020, 9.

12.Bashurina. E. (2021). «Pandemija — vremja bescennogo opyta»: kak perenosjat «koronakrizis» rossijskie social'nye organizacii. FORBES 2021 [Elektronnyj resurs]. URL: https://www.forbes.ru/ forbeslife/424309-pandemiya-vremya-bescennogoopyta-kak-perenosyat-koronakrizis-rossiyskiesocialnye (Data obrashcheniya: 04.06.2020)

13. Amangel'dinova. S.E., Protasova. O.V., Gorkovenko. L.A. (2020) Kazahstan V novyh zhiznennyh realijah $\mathrm{v}$ period pandemii koronavirusa. Innovacionnaja jekonomika: perspektivy razvitija i sovershenstvovanija, 3 (45).

14. Kurultaj social'nyh predprinimatelej programmy "Zharkyra” (2020). FOND EVRAZIJa CENTRAL"'NOJ AZII V KAZAHSTANE. [Elektronnyj resurs] URL: http://www.ef-ca.kz/news/fond/kurultay socialnyh_predprinimate (Data obrashcheniya: 04.06.2020)

15.Bapiev. K. (2020). Kak v Kazahstane razvivaetsja social'noe predprinimatel'stvo. Kursiv. [Elektronnyj resurs]. URL: https://kursiv.kz/news/ biznes/2020-02/kak-v-kazakhstane-razvivaetsyasocialnoe-predprinimatelstvo (Data obrashcheniya: 04.06.2020)

16. Abzhekenova. N. (2020). Chto takoe social'noe predprinimatel'stvo i s kakimi problemami stalkivajutsja igroki jetogo polja v Kazahstane. Karavan 2020 [Elektronnyj resurs]. URL: https:/www.caravan. kz/articles/chto-takoe-socialnoe-predprinimatelstvoi-s-kakimi-problemami-stalkivayutsya-igroki-ehtogopolya-v-kazakhstane-687880/ (Data obrashcheniya: 04.06.2020)

17.Informacionno - analiticheskij otchet SP Askerova Je.H. (2020). V ramkah kompleksnogo social'nogo issledovanija «Social'noe predprinimatel'stvo v Kazahstane. Problematika i puti razvitija» // Nur-Sultan.

18. Asylbek. B. (2020). «Klany vzjali lakomye kusochki i tiho seli na goszakaz». Chto ne tak s kadrovoj sistemoj Minzdrava // Radio Azattyk. [Elektronnyj resurs]. URL: https://rus.azattyq.org/a/corruption-in- the-health-care-system-in kazakhstan/30917536.html (Data obrashcheniya: 04.06.2020)

19. Vitor Gaspar, Martin Mühleisen, Rhoda WeeksBrown. (2020). Korrupcija i pandemija COVID-19. Roskongress. [Elektronnyj resurs]. URL: https:// roscongress.org/materials/korruptsiya-i-pandemiyacovid-19/ (Data obrashcheniya: 04.06.2020)

20. Andreeva. O.V., Kapcova. V.S. (2019). Razvitie idej social'nogo predprinimatel'stva aktual'noe napravlenie nauchnyh issledovanij. Voprosy formirovanija i problemy realizacii nacional'noj tehnologicheskoj iniciativy $\mathrm{v}$ regionah: sbornik dokladov uchastnikov I mezhdunarodnoj nauchnoprakticheskoj konferencii 2019. 258-261.

21.W. Foote. (2020). How Social Entrepreneurs Will Help Us Fight Covid-19 And Build Back Better. Forbes 2020 [Elektronnyj resurs]. URL: https://www. forbes.com/sites/willyfoote/2020/11/17/how-socialentrepreneurs-will-help-us-fight-covid-19-and-buildback-better/?sh=63baaf615c93 (Data obrashcheniya: 04.06.2020)

22.TPP RF. (2020). Programma postkoronavirusnoj rekonstrukcii. Net puti nazad // Kapital strany. [Elektronnyj resurs]. URL: https://kapitalrus.ru/uznai/news/programma_postkoronavirusnoj_ rekonstrukcii_net_puti_nazad_/ (Data obrashcheniya: 04.06.2020) 


\section{Information about the authors}

*Kamshat B. Kanapiyanova - PhD candidate, al-Farabi Kazakh National University, Kazakhstan, e-mail: kanapiyanova.kamshat@gmail.com, ORCID ID: https://orcid.org/0000-0002-6824-7515

Rashid M. Ruzanov - Candidate of Economic Sciences, Deputy Director for General Issues of the Institute of Economics under the Science Committee of the Ministry of Education and Science of the Republic of Kazakhstan, Kazakhstan, e-mail: rashid_ruzanov@mail.ru, ORCID ID: https://orcid.org/0000-0003-4913-3886

Manshuk S. Dosmanbetova- PhD, University of international business, Kazakhstan, e-mail: dmskz@mail.ru, ORCID ID: https://orcid.org//0000-0003-0326-2850

Maral K. Kozhakhmetova - Candidate of Economic Sciences, professor of the Department «Finance and analysis of data» of the University «Narxoz”, Kazakhstan, e-mail: maral.kozhakhmetova@narxoz.kz, ORCID ID: https://orcid. org/0000-0001-7445-787X

Gulmira N. Appakova - professor of the Department “Accounting, Audit and evaluation” of the University «Narxoz», PhD, Kazakhstan, e-mail: ganek310@mail.ru, ORCID ID: https://orcid.org/0000-0001-8512-3824

\section{Авторлар туралы мәліметтер}

*Қанапиянова Камшат Болатқызы - әл-Фараби атындағы Қазақ Ұлттық университетің PhD-докторанты, Қазақстан, e-mail: kanapiyanova.kamshat@gmail.com, ORCID ID: https://orcid.org/0000-0002-6824-7515

Рузанов Рашид Муратбекович - ҚР БҒМ ҒК Экономика институты бас директорының жалпы мәселелер жөніндегі орынбасары, э.ғ.к., Қазақстан, e-mail: rashid_ruzanov@mail.ru, ORCID ID: https://orcid.org/00000003-4913-3886

Досманбетова Маншук Серикбаевна - Халықаралық бизнес университеті, PhD, Қазақстан, e-mail: dms-kz@ mail.ru, ORCID ID: https://orcid.org//0000-0003-0326-2850

Кожахметова Марал Кенебаевна - э.ғ.к., «Нархоз» университетінің «Қаржы және деректерді талдау» кафедрасының профессоры, Қазақстан, e-mail:maral.kozhakhmetova@narxoz.kz, ORCID ID: https:/orcid. org/0000-0001-7445-787X

Аппакова Гульмира Несипбековна - «Нархоз» университетінің «Бухгалтерлік есеп, аудит және бағалау» кафедрасының профессоры, PhD, Қазақстан, e-mail: ganek310@mail.ru, ORCID ID: https://orcid.org/0000-0001$8512-3824$

\section{Сведения об авторах}

*Қанапиянова Камшат Болатқызы - PhD-докторант Казахского национального университета им. аль-Фараби, Казахстан, e-mail: kanapiyanova.kamshat@gmail.com, ORCID ID: https://orcid.org/0000-0002-68247515

Рузанов Рашид Муратбекович - заместитель генерального директора по общим вопросам Института экономики КН МОН РК, к.э.н., Казахстан, е-mail: rashid ruzanov@mail.ru, ORCID ID: https://orcid.org/00000003-4913-3886

Досманбетова Маншук Серикбаевна - Университет международного бизнеса, PhD, Казахстан, e-mail: dmskz@mail.ru, ORCID ID: https://orcid.org//0000-0003-0326-2850

Кожахметова Марал Кенебаевна - к.э.н., профессор, «Финансы и аналитика данных», университет «Нархоз», Казахстан, e-mail: maral.kozhakhmetova@narxoz.kz, ORCID ID: https://orcid.org/0000-0001-7445-787X

Аппакова Гульмира Несипбековна - профессор кафедры «Бухгалтерский учет, аудит и оценка», университет «Нархоз», PhD, Казахстан, e-mail: ganek310@mail.ru, ORCID ID: https://orcid.org/0000-0001-8512-3824 